\title{
THE EFFECT OF COMPANY DIVERSIFICATION TOWARDS EARNING MANAGEMENT MODERATED BY MANAGERIAL OWNERSHIP
}

\author{
Ratih Kusumaningtyas, $\bowtie$ Reni Yendrawati \\ Faculty of Economics, Universitas Islam Indonesia, Yogyakarta, Indonesia
}

\section{Info Artikel}

Sejarah Artikel:

Diterima Juni 2015

Disetujui Juli 2015

Diterbitkan September 2015

\section{Keywords:}

Corporate Diversification;

Earning Management;

Managerial Ownership

\begin{abstract}
This study aims to examine the effect of diversification towards earnings management moderated by managerial ownership. The sample in this research is 48 manufacturing companies listed in Indonesian Stock Exchange period 20092013. Purposive sampling was utilized as a sampling technique in this study. This research used moderating regression analysis to examine the proposed of hypothesis. The result found that diversification has significant positive effect on earnings management. Managerial ownership also has significant positive effect in moderating the relationship between corporate diversification with earnings management. While the three control variables such as company size (size), the company's growth (growth) and leverage have no significant effect on earnings management.
\end{abstract}

\section{THE EFFECT OF COMPANY DIVERSIFICATION TOWARDS EARNING MANAGEMENT MODERATED BY MANAGERIAL OWNERSHIP}

\begin{abstract}
Abstrak
Penelitian ini bertujuan untuk menguji pengaruh diversifikasi terhadap manajemen laba dimoderasi oleh kepemilikan manajerial. Sampel dalam penelitian ini adalah 48 perusahaan manufaktur yang terdaftar di Bursa Efek Indonesia periode 20092013 menggunakan metode purposive sampling. Pengujian dilakukan menggunakan analisis regresi dengan memasukkan model moderasi. Hasil pengujian menunjukkan bahwa diversifikasi berpengaruh positif terhadap manajemen laba. Kepemilikan manajerial juga terbukti berpengaruh signifikan terhadap hubungan antara diversifikasi dan manajemen laba. Sementara variabel kontrol dalam penelitian ini, seperti ukuran perusahaan, pertumbuhan perusahaan serta leverage tidak berpengaruh terhadap manajemen laba.
\end{abstract}

JEL Classification; G3, G31

\footnotetext{
${ }^{\square}$ Correspondence Author: 
Ratih Kusumaningtyas \& Reni Yendrawati / The Effect Of Company Diversification Towards...

\section{INTRODUCTION}

Nowadays, world are facing the new era that is indicated by the tendency to globalization asa result ofmany countries reform the economy. The globalization has pushed the company to be ready to face global competition and drastically change the company strategy, especially marketing strategy and the products. Each company competes in doing marketing strategy to show the existence in business world. That changing makes the company driven to develop the creativity in order to improve and develop the business. One of them is by expanding the amount of business segments or by diversifying operationally as well as geographically.

Generally, diversification strategy is done by company to get relative market power against their competitors. Besides, by implementing diversification, the company expects that if one of the segments has loss, profit can be obtained from other business segment to replace the loss. Based on those reasons, diversification aims to maximize company size, company performance and decrease the risk. However, company diversification generally has a complex organization structure and low transparency. More, it increases processed information complexity by the investors and financial analyst (El Mehdi \& Seuboi, 2011 \& Witiastuti, 2012).

Based on agency theory, company diversification is not optimum because the manager who run diversification tends to direct the diversification for his interest (Lupitasari \& Marsono, 2012). In running the business, manager knows better the internal information and company's prospect comparing to the owner or investors. Imbalance information condition is often named asymmetric information. It can create earning management practices. The more asymmetric information level, the less information got by the owner and financial analyst to see earnings manipulation possibility (El Mehdi \& Sebuoi, 2011).

The relation between diversification and earning management can be seen from the impact resulted from diversification strategy implementation. Diversification will improve the organization, structure and managerial complexity of company (Satoto, 2009). According to agency conflict, the possibility of manager to manipulate the information and earnings depends on the level of organization complexity in company (El Mehdi \& Sebuoi, 2011). In this agency relationship, there is a separation between ownership and management.

The owner gives his authority to the managers to carry out the company and have expectations that the owner can get profits. Agency conflict can be minimized by certain supervision mechanism that fit manager and owner interest, but it results agency cost. There are some alternatives to reduce agency cost, for instance there are an institutional ownership and managerial ownership. Managerial ownership can affect the incentives for management to do the best interest of stockholders (Hermawati, 2012). It is caused that the management can get benefit if the company gets profit. Having this managerial ownership, manager is expected motivated to improve company's performance and minimize the risk faced by company, especially for diversified company.

This study is replication of Aryati and Walansendouw (2013) with developing the research through moderation variable adding of managerial ownership referring to Kurniasari (2013). From the results of previous findings, it is recognized that there is the inconsistent results. That is why, researchers were interested in doing the same research about the effect of business diversification against earning management and added moderation variable of managerial stockholding. This study aims to: examine the effect of company diversification towards earning management moderated by managerial ownership.

\section{Agency Theory}

Agency theory is theory explaining the relationship between owner and management of company. Gudono (2009) stated that agency 
theory is built as an effort to understand and solve the raising problem if asymmetric information is found in contract between principal and agent. The owner gives his authority to the managers to carry out the company and have expectations that the owner can get profits in the form of wealth and welfare.

\section{Company Diversification}

Diversification is a kind of business development by expanding the amount of business segments both operationally as well as geographically, expanding the existing market share and improving various products (Kurniasari, 2013). Anthony and Govindrajan (2011) divided diversification strategy into two types; they are related diversification and unrelated diversification. Related diversification is a type of diversification that has relation among its business units. Unrelated diversification is a type of diversification that has little or has no relation at all among each other business units.

\section{Earnings Management}

Five techniques and earning management pattern according to Sulystyawan et al. (2011): (1) changing the accounting method; (2) making the accounting estimation; (3) changing the period of revenue recognition and cost; (4) reclassifying the account and (5) reclassifying discretionary and non-discretionary accruals. According to Sulistyanto (2008), earning management is an effort of company manager to interfere or influence the information to manipulate the stakeholder who wants to know the performance and condition of the company. Scott (2000) divided earning management that may be done by company manager into 4 patterns of earning management.

\section{Managerial Ownership}

According to Putra and Wirawati (2013), managerial ownership is percentage of stock ownership by management. The managers as stockholder will try to work optimum, more the self-interest will not be included. Management always tries to improve the performance and value of the company. Improving the performance and value of the company makes the wealth owned as stockholders will increase. As a result, welfare of the stockholders will increase too.

\section{TheEffect of Business Diversification towards Earning Management}

According to Lupitasari and Marsono (2012), diversification is a kind of business development by expanding the amount of business segments both operationally as well as geographically, expanding the existing market share and improving various products. Diversified company will have bigger asymmetric information comparing to focused company. It is caused by diversified company is less transparency comparing to focused company. (Rodriguez-Perez \& Van Hemmen, 2010).

El Mehdi and Seboui (2011) contend that diversification can strengthen the asymmetric information, because various culture and support missed allocation of investment. It makes the managers can exploit the asymmetric information through earning management. Herrmann (2009) asserts that company diversification improves earning management. It is caused by higher level of company diversification, the less transparency it has.

$\mathrm{H} 1$ : company diversification gives positive impact towards earning management.

\section{Managerial Ownership Moderates the Effect of Diversification towards Earning Manage- ment}

The relationship between company diversification and earning management can be strengthened by managerial ownership. The bigger proportion of managerial ownership, managers will tend to be more active for the interest of stockholders (Kurniasari \& Purwanto, 
Ratih Kusumaningtyas \& Reni Yendrawati / The Effect Of Company Diversification Towards...

2012). The managers as the stockholders are motivated to improve company's performance by decreasing earning management to increase the welfare.

Chin et al. (2010) alleges that there is a negative relationship between international diversification and earning management in the company which has bigger controlling stockholders structure. It means that bigger controlling ownership will be able to control the company's performance better through reducing the earning management. Therefore, even if the company has a lot of business diversifications, the relationship between business diversification and earning management is still low. It is caused the company placed bigger controlling stockholders ownership.

On the contrary if controlling stockholders ownership is smaller, the relationship between business diversification and earning management will be stronger. Based on those things, alternative hypothesis in this research is proposed as follows:

$\mathrm{H} 2$ : Managerial ownership moderates the effect between diversification towards earning management.

\section{Framework of the Study}

Based on the previous theory and research analysis, the framework of the study can be drawn as Figure 1.

\section{METHOD}

Populations of the study are all registered manufactured in Indonesia stock exchange. The period of observation was in the year of
2009-2013. The sample company was chosen based on purposive sampling, such as registered in Indonesia stock exchange in the period of 2009- 2013, publish the financial report from 2009-2013, the company has diversification and ownership managerial from 2009-2013, the company has positive consecutive earning from 2009-2013 on the Table 1.

Before doing hypothesis test, the classic assumption test will be conducted first. The test includes normality, multicollinearity, heteroscedasticity and autocorrelation test. To examine the hypothesis, this research used linear regression analysis with equation as follow:

$$
\begin{aligned}
& \text { ABS_DA }=\alpha+\beta_{1} \mathrm{DIV}+\beta_{2} \mathrm{MANJ}+\beta_{3} \mathrm{DIV}^{*} \mathrm{MANJ}+ \\
& \beta_{4} \mathrm{LEV}+\beta_{5} \text { SIZE }+\beta_{6} \text { GROWTH } \\
& \alpha \quad=\text { Constants } \\
& \beta 1-\beta 6=\text { Regression coefficient } \\
& \text { ABS_DA = Earning management } \\
& \mathrm{DIV}^{-}=\text {Company Diversification } \\
& \text { MANJ = Ownership managerial } \\
& \text { LEV = Leverage } \\
& \text { Size = Company size } \\
& \text { Growth = Company Growth } \\
& \mathrm{E}=\text { Error }
\end{aligned}
$$

\section{RESULT AND DISCUSSIONS}

The research was done in Manufacture Company of Indonesia stock Exchange in the period year of 2009-2013. Based on the selected sample, it is obtained 46 manufacture companies who pass the selection of samples by purposive sampling method. Descriptive analysis toward the research variables on the average description and standard deviation of each variable can be shown on the Table 2 .

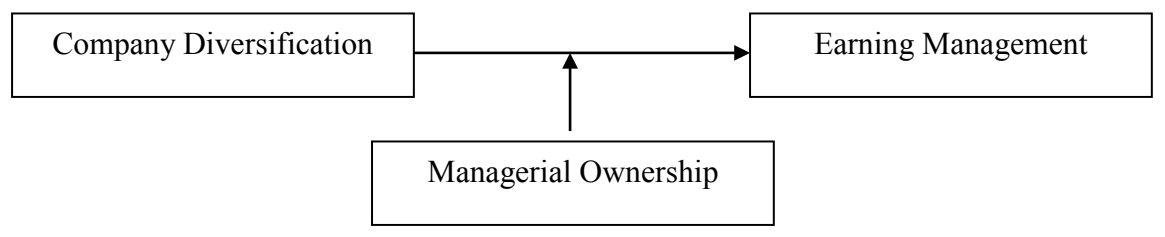

Figure 1. Framework of the Study 
Table 1. Variable Measurement

\begin{tabular}{|c|c|c|}
\hline No & Variable & Proxy \\
\hline \multirow[t]{2}{*}{1.} & Diversification & Herfindahl Diversification index : (Hallara, 2010) \\
\hline & & $\sum(\text { SSale / Sales })^{2}$ \\
\hline 2. & Earning management & $\begin{array}{l}\text { Modified Jones Model (Discretionary Accruals): (Walansendouw, } \\
\text { 2013) } \\
\text { DAit = TAit / Ait-1 - NDAit }\end{array}$ \\
\hline \multirow[t]{3}{*}{3.} & Ownership managerial & Ownership managerial (stock ownership proportion of the manager) : \\
\hline & & $\mathrm{MANI}=$ the number of stock owened by manager \\
\hline & & Total of the stock \\
\hline \multirow[t]{4}{*}{4.} & $\begin{array}{l}\text { Control variable (Size, } \\
\text { Growth, Leverage) }\end{array}$ & Size $\quad=\log ($ Total Asset $)$ \\
\hline & & Leverage $=\frac{\text { Total debt }}{}$ \\
\hline & & Total Equity \\
\hline & & Growth $=\frac{\left(\text { Sales }_{t}-\text { Sales }_{t-1}\right)}{\text { Sales }_{t-1}} \times 100 \%$ \\
\hline
\end{tabular}

Source: data processed (2015)

Table 2. Descriptive Analysis

\begin{tabular}{lccccc}
\hline & N & Minimum & Maximum & Mean & Std. Deviation \\
\hline DA & 230 & 0.001 & 0.463 & 0.087 & 0.084 \\
DIV & 230 & 0.266 & 1.000 & 0.681 & 0.222 \\
MANJ & 230 & 0.000 & 25.610 & 1.641 & 4.639 \\
DIV.MANJ & 230 & 0.000 & 25.610 & 1.360 & 4.067 \\
LEV & 230 & 0.035 & 412.260 & 3.287 & 27.630 \\
SIZE & 230 & 10.280 & 14.330 & 12.488 & 0.724 \\
GROWTH & 230 & -0.999 & 923.878 & 4.334 & 60.917 \\
\hline
\end{tabular}

Source: data processed (2015)

From the descriptive analysis above, it shows that the average variables of the earning management were 0,087 with standard deviation of 0,084 . It means that the average of company shows a positive earning so the company tends to do earning management in reporting yearly financial report. The standard deviation value of 0.084 is smaller than average value. It means that variability level data distribution of the earnings management is low enough.
For level variable of company diversification which is by proxy with Herfindahl index, where Herfindahl index is obtained by summing up all squared value of sales of each segment divided by the total sales of the company, it is obtained minimum value of 0,266 , the maximum value of 1.000 , the average value of 0.681 , and standard deviation of 0.222 . The diversification of 0.681 indicates that company diversification is quite spread, 
Ratih Kusumaningtyas \& Reni Yendrawati / The Effect Of Company Diversification Towards...

so it has had various segments in product sales. With the standard deviation which is smaller than the average value, it can be seen that sample for company diversification variable is accepted because level of deviation is not as big as the average.

The managerial ownership result analysis obtained minimum value of $0,463 \%$ the maximum value of $25,61 \%$, the average of $1,641 \%$ and the standard deviation of 4,639. This result shows the stock average owned by manager was $1,641 \%$ from the total ownership of existing stock. Standard deviation value is higher than the averages, means the data distribution of ownership managerial was quite fluctuated between one companies to another company. For the company measurement variable (SIZE) in a company, the calculation used logarithm from total active from each company sample.

From the research, it is obtained minimum value of 10.280 , maximum value of 14.330 , average value of 12.488 , and standard deviation of 0.724 . For leverage variables (LEV) in current company which is counted by comparing the total debt with total equity from each companies sample, it is obtained minimum value of 0.035 , maximum value of 412.260 , average value of 12.488 , and standard deviation of 0.724 . The average value of this variable is 12.488 , indicates the average total debt from the sample company is 12.488 times from the total equity.
To simplify the calculation of the regression of the data which are quite a lot, this research used the program SPSS 16 as the software to analyze the data. This regression analysis used Moderating Regression Analysis. The result of the regression can be shown on the Table 3. By regression model and the result of linear regression, it can be written the equation of the regression as follow:

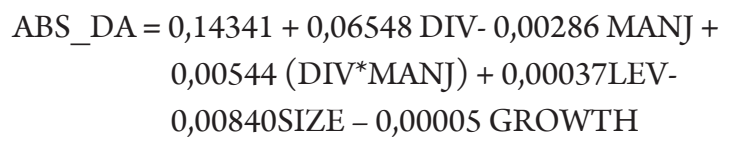

Based on the data analysis, it is found the variable of diversification level by proxy of Herfindahl Index that has value of 2.613 with the significance value of 0.010 . Significant value of $0.010<\alpha=0.05$ means that company diversification significantly gives positive effect towards earning management. Therefore, the hypothesis stated that company diversification gives positive effect towards earning management can be supported.

Lupitasari and Marsono (2012) claimed that diversified company has high level of asymmetric information and less transparency comparing to non-diversified company since it has more complex structure. El Mehdi and Seboui (2011) have the same idea. Diversification can create strong asymmetric information, various cultures and support misses

Table 3. Regression Analysis

\begin{tabular}{llccccc}
\hline \multirow{2}{*}{ Model } & \multicolumn{2}{c}{$\begin{array}{c}\text { Unstandardized } \\
\text { Coefficients }\end{array}$} & $\begin{array}{c}\text { Standardized } \\
\text { Coefficients }\end{array}$ & t & Sig. \\
\cline { 3 - 5 } & B & Std. Error & Beta & & \\
\hline 1 & (Constant) & 0.14341 & .099 & & 1.444 & .150 \\
DIV & 0.06548 & .025 & .173 & $2.613^{*}$ & .010 \\
MANJ & -0.00286 & .002 & -.158 & -1.797 & .074 \\
DIV.MANJ & 0.00544 & .002 & .263 & $2.854^{*}$ & .005 \\
LEV & 0.00037 & .000 & .123 & 1.905 & .058 \\
SIZE & -0.00840 & .008 & -.072 & -1.078 & .282 \\
GROWTH & -0.00005 & .000 & -.033 & -.517 & .606 \\
\hline F Statistic & 4.956 & & & & \\
Sig-F & 0.000 & & & & \\
Adjusted R & & & & & & \\
\hline
\end{tabular}

Source: data processed (2015) 
allocation of investment. It caused the managers can exploit the asymmetric information through learning management. Having the complexity, earning management in diversified company is greater because there is a possibility that stockholders do not have incentives, resources and enough information access to control the manager. It needs more resources and expertise to check the income from some divisions.

Based on moderation test results, it is found that moderation variable of diversification level and managerial ownership (DIV*MANJ) is 2.854 , with significance value of $0.005<\alpha=0.05$. It means that managerial ownership which give significant effect in moderate the relationship between company diversification towards earning management can be supported. Company that has bigger managerial ownership has stronger relationship between company diversification and company value. Managerial ownership is stock ownership that is had by company management measured by the percentage amount of stock owned by management. The amount of managerial ownership indicates the same interest between management and stockholders/owner.

The relationship between corporate diversification and earning management can be strengthened by managerial ownership. The bigger proportion of managerial ownership, managers will tend to be more active for the interest of stockholders; it is himself (Kurniasari \& Purwanto, 2012).

The managers as the stockholders are motivated to improve company's performance by decreasing earning management to increase the welfare. It is expected that diversified company can decrease the earning management because the managers try to improve the performance in the name of stockholders and their interests. Managerial ownership can help to decrease opportunistic behavior of the managers. The amount of managerial ownership indicates the same interest between management and stockholders/owner (Kurniasari \& Purwanto, 2012). The bigger proportion of managerial ownership, managers will tend to be more active for the interest of stockholders; it is himself.

Chin et al. (2010) alleges that there is a negative relationship between international diversification and earning management in the company which has bigger controlling stockholders structure. It means that bigger controlling ownership will be able to control the company's performancebetter through reducing the earning management. Therefore, even if the company has a lot of business diversifications, the relationship between business diversification and earning management is still low. It is caused the company placed bigger controlling stockholders ownership.

On the contraryif controlling stockholders ownership is smaller, the relationship between business diversification and earning management will be stronger. Leverage control variable has value of $t_{\text {count }}$ is 1.905 with sig value is 0.058 . Sig value is $0.058>\alpha=0.05$, it means that leverage variable is not significant at $5 \%$ so it can be concluded that leverage is not give significant effect to earning management.

Company size controlvariable (SIZE) has $\mathrm{t}_{\text {count }} 1.078$ with sig value is 0.282 . Sig value is $0.282>\alpha=0.05$, it means company size control variable (SIZE) is at $5 \%$ so it can be concluded that company size (SIZE) is not give significant effect towards earning management. Company growth control variable (GROWTH) has $\mathrm{t}_{\text {count }}$ -0.517 with sig value is 0.606 . Sig value of 0.606 is bigger than $\alpha=0.05$. It means that company growth control variable (GROWTH) is not significant at level of $5 \%$ so it can be concluded that company growth control variable (GROWTH) is not give significant effect towards earning management.

Company that has earning management does not depend on the amount of its debt, size and growth of company, but it is done because company wants to influence the market performance in short term period. Company reports understated when buy out is done and overstated when offering the public share is done. 
Ratih Kusumaningtyas \& Reni Yendrawati / The Effect Of Company Diversification Towards...

\section{CONCLUSION}

The conclusions based on the research are mentioned below. Company diversification level (proxy by Herfindahl Index) effects earning management (proxy by discretionary current accruals). The higher level company diversification, the higher possibility to do earning management. Managerial ownership significantly moderates towards earning management. It means that if the managerial ownership is higher, the effect of company diversification towards earning management is higher too. On the contrary, if the managerial ownership is lower, the effect of diversification towards earning management is lower too.

Researchers realized that this study still has weakness because of some following limitations the lowest value of adjusted $R^{2}$ is $9,4 \%$. It means that the variable used in the research has only 9.4\% in explaining the earning management phenomena. Other variable adding is needed to influence the earning management action. Diversification measurement in this research only measured sub segments so it was not able to measure until the smallest unit of sales. It is caused by the limitation of financial statement reporting segment information. The segment information had included the sub segment's groups.

Based on the research results and limitation of the researchers, it can be suggested to the researcher, it is needed to consider other variables that is expected influencing the earning management, for instance audit quality, auditor independency, and company profitability. It is also needed to develop the size of company diversification using other methods or formulas. The next research, it is expected to be able to firstly choose the company financial statements showing in detail each smallest subsegment sales since it is not all companies show the information about the business segments in detail. Diversified company, it is needed a lot of considerations in doing earning management to make the information in financial statement shown is not bias and can be shown as it is.

\section{REFERENCES}

Anthony, R. N \& Govindarajan, V. 2011. Sistem Pengendalian Manajemen, Edisi keduabelas. Tangerang: Karisma Publishing Group.

Aryati \& Walansendouw, C. 2013. Analisis Pengaruh Diversifikasi Perusahaan Terhadap Manajemen Laba. Jurnal Akuntansi \& Auditing. 9 (2): 244-260.

Chin, C. L., Chen, Y. J \& Hsieh, T. J. 2009. International Diversification, Ownership Structure, Legal Origin, and Earnings Management: Evidence from Taiwan. Journal of Accounting, Auditing and Finance. (24): 233.

El Mehdi, I. K. \& Seboui, S. 2011. Corporate Diversification and Earnings Management. Review of Accounting and Finance. 10 (2): 176196.

Gudono. 2009. Teori Organisasi. Yogyakarta: BPFE.

Hallara, S. 2010. The Impact of Diversification on Firm Performance and Risk: An Empirical Evidence. International Research Journal of Finance and Economic. 35: 150-162.

Herrmann, T. K. 2010. Diversification and Management Earnings Guidance the Effects of Reg F. Journal of International Accounting Research. 9 (1): 1-22.

Hermawati, A. 2012. Pengaruh Kinerja Keuangan Terhadap Nilai Perusahaan Dengan Pengungkapan Corporate Social Responsibility Dan Struktur Kepemilikan Sebagai Variabel Pemoderasi.Jakarta: Universitas Gunadarma.

Kurniasari, S. E. 2013. Pengaruh Diversifikasi Usaha Terhadap Kinerja Perusahaan Yang Dimoderasi Oleh Kepemilikan Manajerial. Jurnal Akuntansi Fakultas Ekonomi dan Bisnis Universitas Dian Nuswantoro. 7 (3): 15-19.

Kurniasari, A \& Purwanto, A. 2012. Pengaruh Diversifikasi Korporat Terhadap Kinerja Perusahaan Dan Risiko Dengan Moderasi Kepemilikan Manajerial. Diponegoro Journal of Accounting. 1 (1): 12-16.

Lupitasari, D \& Marsono. 2012. Diversifikasi Perusahaan Dan Manajemen Laba. Diponegoro Journal of Accounting. 1 (1): 6-13. 
Jurnal Dinamika Manajemen Vol. 6, No. 2, 2015, pp: 178-186

Putra, I. K \& Wirawati, N. G. P. 2013. Pengaruh Kepemilikan Manajerial Terhadap Hubungan Antara Kinerja Dengan Nilai Perusahaan. Jurnal Akuntansi Universitas Udayana. 12 (2)

Rodriguez, P. G \& Hemmen, S. V. 2010. Debt, Diversification and Earnings Management. Journal of Accounting and Public Policy. 29 (2).

Satoto, H. S. 2009. Strategi Diversifikasi Terhadap Kinerja Perusahaan. Jurnal Keuangan Dan Perbankan. 13 (2): 280-287.
Scott, R. W.2009. Financial Accounting Theory. Second Edition. Canada: Prentice Hall Canada Link, Scarborough.

Sulistyanto, S. 2008. Manajemen Laba: Teori dan Model Empiris. Jakarta: Grasindo.

Witiastuti, R. S. 2012. Analisis Kinerja Portofolio: Pengujian Single Index Model Dan Naive Diversification. Jurnal Dinamika Manajemen. $3(2)$. 